Academic City University College - Accra Ghana

Society for Multidisciplinary \& Advanced Research Techniques (SMART) Africa

Tony Blair Institute for Global Change

FAIR Forward - Artificial Intelligence for All - Deutsche Gesellschaft für Internationale Zusammenarbeit (GIZ) GmbH

Accra Bespoke Multidisciplinary Innovations Conference (ABMIC)

\title{
Leveraging On Capital Market for Sustainable Development in Nigeria
}

Ilemobayo, Akinwumi Simeon ${ }^{1}$ \& Onyenebo, Innocent Ndubisi ${ }^{2}$

Department of Banking and Finance ${ }^{1}$

Department of General Studies, SPTS 2

Lagos State Polytechnic, Ikorodu, Lagos

Email: ilemobayoas@gmail.com; onyeneboinnocent@yahoo.com

Phones: +234 8033189957; +2348032384281

Member Proceedings Citation Format

Ilemobayo, A.S. \& Onyenebo, I.N. (2021): Leveraging On Capital Market for Sustainable Development in Nigeria. Proceedings of the Accra Bespoke Multidisciplinary Innovations Conference. University of Ghana/Academic City University College, Accra, Ghana. December 2021. Pp 210-222. www.isteams.net/ghanabespoke2021.

DOI https://doi.org/ 10.22624/AIMS/ABMIC2021-V2-P16 


\title{
Leveraging On Capital Market for Sustainable Development in Nigeria
}

\author{
Ilemobayo, Akinwumi Simeon \& Onyenebo, Innocent Ndubisi
}

\begin{abstract}
The role of capital market in economic growth and development and sustainable development cannot be relegated, hence this paper attempted to examine how capital market can be used to attain sustainable development in Nigeria. This paper becomes relevant in view of the fact that there has not been much work in this area and therefore fills that gap. Time series data collected for a period of 20 years spanning from 2000 to 2020. The dependent variable was Real Gross Domestic Product which served as proxy for sustainable development while other variable in the model were the independent variables. The Augmented Dickey Fuller test were used to test for the stationarity of the variables to avoid inconsistent and spurious data. The existence of long run relationship between the dependent and the independent variables were ascertained through the Johansen cointegration test. The granger causality were also tested to determine the direction of the variables and the Error Correction Model (ECM). The model were estimated using the OLS method. The results shows that $96 \%$ variations in the RGDP are explained in the model. The overall fitness of the model is explained by the F-Statistics value of 11.3 with a low probility of less than $5 \%$. Findings reveals that the All Share Index (ASI), Market Capitalisation (MAC) and Number of Listed Companies (NIC) have positive but insignificant effect on sustainable development while Number of Listed Securities (NIS), Interest Rate (INR) and Inflation Rate (INF) all have negative and insignificant effect on sustainable development. It is therefore recommended that for capital market to lead to sustainable development, the more securities should be listed on the floor of the stock exchange, while the rate of interest rate and inflation rate should be reduced.
\end{abstract}

Keyword: Stock Market, Economic Growth, Development, Sustainable Development, Nigeria.

\section{INTRODUCTION}

The global economy are confronted by myriad of challenges ranging from environmental, social and corporate governance that have a far reaching consequences that threaten its existence and to overcome these challenges require an enormous amount of financial resources (IDB Invest, 2021). To achieve the Sustainable Development Goad (SDG) a target set by the United Nations Development Programme (UNDP), global investment need is the range of $\$ 5$ to $\$ 7$ trillion per annum in other to deliver the SDG by 2030 , with developing nations in need of around $\$ 3.3$ to $\$ 4.5$ trillion yearly but having current investment at $\$ 1.4$ trillion thereby having an investment short fall of about $\$ 1.9$ and $\$ 3.1$ trillion annually (UNCTAD, 2014). Tapping into capital market becomes necessary in other to achieve this loudable objective

Financial market plays a vital role in the growth and development of nations as it serves as a medium through which resources are channeled from the surplus sector to deficit sector for industrialisation, growth, development and sustainable development. The extent to which the financial market is development determines the rate of growth of the economy. According to Ehigiamusoe (2012), the role of the financial market is so important that it can promote or mar economic growth and development. 
Financial market is made up of stock market, equity market, derivative market and commodity market. Capital market, money market and financial intermediaries are all part of the financial market. According to Alam and Hussein (2019), the absence of capital market in any nation will inhibit industrial development. Financial markets efficiently direct the flow of savings and investment in the economy in ways that facilitate the accumulation of capital and the production of goods and services. Financial markets helps in price determination, fund mobilisation, liquidity, risk sharing, provision of financial information and capital formation.

Capital market is crucial not only to the growth and development of any nations but also for sustainable development. Capital market helps in channeling funds from the surplus unit to the deficit unit for growth and expansion. Just as the organised corporate world turns to capital market when in need of funds for long term purpose such as for business expansion, nations of the world leverage on capital market to obtain the desired amount of capital for development projects especially infrastructure which not only contribute to the immediate generation but also for future generations. Mishra, Mishra, Mishra and Mishra (2010) opined that policy makers, researchers and academicians have all recognised the immeasurable roles played by capital market in developed and developing economies through financial intermediation. Raising capital for growth, development and sustainable development through the capital market depends on three factors; first the speed of development of the capital market; secondly the mobilisation of domestic savings and thirdly the rate foreign capital inflow. According to Oteh (2018) to meet Sustainable Development Goal (SDG), developing countries need to invest \$3.9 trillion annually but currently invest $\$ 2.5$ trillion leaving an investment gap of $\$ 1.4$ trillion annually, the annually investment gap can be bridged through capital market.

The absence of a well developed stock market will mar the performance of the capital market as the capital market cannot work in isolation from the stock market. Finance is key to the attainment of macroeconomic objectives. No matter how feasible and viable a project is, without finance, such project will not see the light of the day. According to Babalola and Adegbite (2001) funds are need for production to be undertaking which will lead to growth in the economy. Long term funds are needed to attain deserved level of economic growth that will spur sustainable development. African countries have remained under developed due to none availability long term funds (Ogboi \& Oladipo, 2012). Sustainable development can only be achieved when capital is sourced by both the public and private sectors.

Nigeria's search for growth and development began with the introduction of First National Development Plan in 1962. Since then other development plan and policy thrust have been rolled out by successive government to harness the opportunities available for growth and development. The enormous financial resources required for growth has outweighed many nations as they cannot single handedly finance their developmental programmes. Hence sourcing funds from the capital market becomes inevitable in the face of dwindling internally generated revenue (IGR).

One question that has occupied economic discuss is the rate of disparity in economic growth and development among nations of the world (Oluwole, 2014). Many sectors in Nigeria have remained underdeveloped due to paucity of funds. These sectors are critical to the attainment sustainable development. The Structural Adjustment Programme in 1986 and the financial liberalisation opened up the need for capital market. Riman, Esso and Eyo (2008), the increase in the level of patronage by the public and private investor is an indication of the level of transformation that the Nigerian stock exchange has undergone over the years. 
The performance of the capital market has shown significant improvement over the years going by the performance of market indicators. Market capitalisation rose $\$ 1,698.1 \mathrm{~m}$ in 1980 to \$472.3b in 2000 and to all time of $\$ 41,329.19$ in 2013. In the same vein the number of listed companies in 2000 was 260 which rose to 305 in 2007 before declining to 177 in 2020. The number of listed securities on the floor of the Nigerian stock exchange was 1,021,967 in 2005 as against 256,563 in 2000 (CBN Annual Report 2000 - 2020). In spite of these enormous prospects which the capital market has shown over the years, attention of researchers, economist and financial analyst has been limited to economic growth and development without considering how capital market can be leveraged to attain sustain development that meet the need of the present and preserve for future generation hence this paper fills that gap.

The objective of this paper is to determine how Nigeria and indeed developing nations can leverage on capital market to attain sustainable development. In effect this paper considers the effect of all share index, market capitalization, number of listed companies, number of listed securities, interest rate and inflation on sustainable development.

\section{LITERATURE REVIEW}

\section{Conceptual Review}

The Capital Market

Capital market is a market for long term borrowing. The capital market consists of the primary market which is a market for new issues and secondary market for the resale of existing stocks. The performance of the economy depends largely on the activities of the capital market (Emeh \& Chigbu, 2014). On the other hand, Dowan and Odia (2010) opined that developed and rising economies got to where they are today through the help of capital market. Capital markets helps economic agents to spread their risk (Osho, 2014). Capital market can be accessed by the government, corporate organisations and the individuals.

While the government trade only bonds in the market, corporate organisations trade both bond and equity. According to Oganga (2019) organised capital market is one that is controlled and regulated by a body with rules and laid down regulations while unorganised capital market is one that predominantly dominated by local lenders who lend out money to their immediate neighbour and community at an agreed fixed interest rate. Al-Faki (2006) views capital market as "network of specialized financial institutions, series of mechanisms, processes and infrastructure that, in various ways, facilitate the bringing together of suppliers and users of medium to long term capital for investment in socio-economic developmental projects".

\section{Functions of the Nigerian Capital Market}

(a) The Nigerian capital market encourages savings and investment

(b) It serves as link between investors and savers.

(c) It promotes economic growth

(d) It ensures stability of prices of traded securities

(e) It helps to provide funds for long term projects.

(f) It provides avenue for economic agents to participate in economic activities.

(g) It ensures effective allocation and re-allocation of financial resources for optimal production. 


\section{Roles of the Nigerian capital Nigeria}

The roles of the capital market in the macroeconomic structure of Nigeria include but not limited to the following:

(a) It provides opportunities for companies to borrow funds needed for long-term investment purposes.

(b) It provides avenue for the marketing of shares and other securities in order to raise fresh funds for expansion of operations leading to increase in output/production.

(c) It provides a means of allocating the nations real and financial resources between various industries and companies. Through the capital formation and allocation mechanism the capital market ensures an efficient and effective distribution of the scarce resources for the optimal benefit to the economy.

(d) It reduces the over reliance of the corporate sector on short term financing for long term projects and also provides opportunities for government to finance projects aimed at providing essential amenities for socioeconomic development.

(e) The capital market can aid the government in its privatization programme by offering her shares in the public enterprises to members of the public through the stock exchange.

(f) The capital market also encourages the inflow of foreign capital when foreign companies or investors invest in domestic securities, provides needed seed money for creative capital development and acts as a reliable medium for broadening the ownership base of family-owned and dominated firms

\section{Sustainable Development}

Sustainable development has become a road map to steer socio and economic change of the world (Shi, Han, Yang \& Gao, 2019). The concept of sustainable development can be viewed from different perspective going by the UNDP 17 Sustainable Development Goal (SDG) and 169 targets to be achieved by year 2030. Sustainable development will be a mirage in the absence of growth and development over time. Sustainable development is simply seen as meeting the yearnings of the present generation and making sure that the future generations meet their own need. UNDP (2015) Sustainable Development Goals which is aimed at eradicating poverty, protect the planet and ensure prosperity for all by year 2030 will not be attained in the absence of capital. According to Schepers and Sethi (2003) cited in Busch, Bauer and Orlitzky (2015), capital market has not contributed so much to the attainment of sustainable development. Capital market was the rallying point for England's industrial revolution (Bagehot, 1873).

How capital market can build sustainable development in Nigeria.

The role played by capital market in the following instance can be extended to building not only economic growth and development but also sustainable development.

(a) Capital market can help to finance government infrastructure.

(b) Capital market was active during the period of $\$ 25$ billion bank re-capitalisation and consolidation in Nigeria.

(c) It was noticed that capital market was actively involved in the period of privatisation and commercialisation of state owned enterprises.

(d) It is an avenue for increased foreign direct investment for economic expansion. 


\section{Theoretical Review}

The theory of sustainable development has evolved through three different phases according to Shi, Han, Yang and Gao (2019) these are:

Embryomic period (before 1972): The term sustainability was first used in the 20th century and the idea of sustainability can attributed to China. In this period the emperor found out that mountains, forest and rivers and other natural endowments can be used in accordance with nature rather than for exploitations. Following this, different laws were enacted to protect natural resources and creating an enabling environment for them to grow.

Molding Period (1972 - 1987): In this period the United Nations Conference on the Human Environment in 1972 and the Publication of our Common Future in 1987 were steps taking at this stage. With the recognition that the developmental policies primarily focusing on economic growth increased the frequency of serious environmental problems, the United Nations held a world summit in Stockholm, Sweden in 1972. In 1987, the World Commission on Environment and Development (WCED) drafted a report on human development, "Our Common Future", which was the first time to systematically stated the definition of sustainable development. The report focused on the global situation of the population, food, species and genetic resources, energy, industry, human habitation.

The developing period (1987 - date): Many reforms have taken place at this stage, which include United Nations Conference on Environment and Development (1992) that was held in Rio de Janeiro, Brazil, in 2000 United Nations Millennium Submit was held. Other summits held were the United Nations Conference on Sustainable Development in 2012 and the United Nations Sustainable Development Summit in 2015.

\section{Empirical Review}

Donwa \& Odia (2010) while investigating capital market and Nigeria's socio economic development concluded that capital market has not contributed significantly to the growth of the economy and therefore recommended that adequate measures should be put in place to make the stock market more viable, this will not only results in more investment opportunities but will also restore the confidence in the investing public this will bring about the much needed socio-economic development in the country.

Busch, Bauer and Orlitzky (2015). The paper focuses on the role financial markets plays in the achievement of sustainable development. The paper ascertained that the capital market has played a modest role in sustainable development. Financial market participants increasingly integrate environmental, social, and governance into their investment decisions. Two main challenges were identified in the field of sustainability. The paper identifies the potential market consequences.

Udo, Nwezeaku and Kanu (2021) studies the effect of capital market development on the economic growth of Nigerian using time series data from 1983 to 2016 . The Autoregressive Distribution Lag (ARDL) was used to estimate the model. Findings from the study reveal that All Share Index and number of listed securities are positively correlated with economic growth in Nigeria both in the short and long run. The paper recommend that factors that hinder the growth of the capital market both in the short and long run should be removed by the government. The paper identified such factors as tax, legal and regulatory barriers. 
Alam and Hussein (2019) investigates how capital market has used to achieve Omani's economic growth using real Gross Domestic Product (GDP) as representative for economic growth. The main objective of the paper was focused on Muscat Security Market (MSM). The data were collected from the different official MSM annual reports, Central Bank of Oman annual reports and the World Bank Development Reports. The technique applied involved the use of multiple regression analysis to find the influence of the capital market on the Omani GDP. The analysis so far confirmed that there is a positive relationship between capital market and economic growth in Oman for the investigated period. So, it is recommended that, Oman should place greater emphasis on financial sector development with special focus on capital market development to ensure economic growth.

\section{METHODOLOGY}

The sources of data were from the various of the Central Bank of Nigeria and the National Bureau of Statistics. The dependent variable was Real Gross Domestic Product (RGDP) which was proxy for sustainable development. The independent variables were All share index, market capitlisation, number of listed companies, number of listed securities, inflation and interest rate. The time series data collected were from 2000 to 2020 spanning a period of 20 years. The model was estimated using the Ordinary Least Square Method (OLS).

$\begin{array}{ll}\text { Model Specification } \\ \text { RGDP = a1 + a2ASL + a3MAC+a4NIC +a5NIS + } \\ \text { Where: } \\ \text { RGDP }= & \text { Real Gross Domestic Product } \\ \text { ASL }= & \text { All Share Index } \\ \text { MAC }= & \text { Market Capitalization } \\ \text { NIC }= & \text { Number of Listed Companies } \\ \text { NIS }= & \text { Number of Listed Securities } \\ \text { INR }= & \text { Interest Rate } \\ \text { INF }= & \text { Inflation Rate } \\ \mathrm{U}_{\mathrm{t}}= & \text { Stochastic variable (error term) } \\ \mathrm{A}_{1}= & \text { Intercept } \\ \mathrm{A}_{2}, \mathrm{a}_{3} \mathrm{a}_{4} \mathrm{a}_{5}= & \text { Slope }\end{array}$




\section{DATA PRESENTATION AND ANALYSIS}

\section{Unit Root Tests}

Table 1

\begin{tabular}{|c|c|c|c|c|c|c|}
\hline $\begin{array}{l}\text { S/ } \\
\text { No }\end{array}$ & Var & $\begin{array}{l}\text { Adf Statistic At } \\
\text { Level }\end{array}$ & $\begin{array}{l}\text { Critical Value } \\
5 \%\end{array}$ & $\begin{array}{l}\text { Adf Statistic } 1^{\text {st }} \\
\text { Difference }\end{array}$ & $\begin{array}{l}\text { Critical Value } \\
(5 \%)\end{array}$ & $\begin{array}{ll}\text { Order } & \text { Of } \\
\text { Integration. }\end{array}$ \\
\hline 1 & $\begin{array}{l}\text { RG } \\
\mathrm{DP}\end{array}$ & 0.0930 & -3.0656 & -3.4194 & -3.0656 & $1(1)$ \\
\hline 2 & ASI & 0.6689 & -3.0299 & -1.6188 & -3.0409 & 1(1) \\
\hline 3 & MAC & 0.1287 & -3.0206 & -0.9441 & -3.0299 & 1(1) \\
\hline 4 & $\mathrm{NIC}$ & 0.3066 & -3.0206 & -1.4425 & -3.0299 & 1(1) \\
\hline 5 & NIS & -0.4678 & -3.0206 & -1.0962 & -3.0299 & $1(0)$ \\
\hline 6 & INR & -0.4970 & -3.0206 & -1.1966 & -3.0299 & $1(0)$ \\
\hline 7 & INF & -0.8585 & -3.0206 & -1.4587 & -3.0409 & $1(0)$ \\
\hline
\end{tabular}

Source: Authors' computation 2021

The augmented Dickey Fuller (ADF) test of unit roots was conducted for all the time series (including a deterministic trend), which were used in the study. The ADF results showed that all the variables were non-stationary at their levels. The test results revealed that the series were all integrated of order I(0) and I (1). ADF result shows that number of listed securities, interest rate and inflation rate in relation to real gross domestic product is negative at level. All share index, market capitalization and number of listed companies in relation to real gross domestic product are positive at order of integration (1) hence there is positive relationship between all share index and sustainable development in Nigeria.

Co-integration Results:

.Table 3a: Normalized co-integrated coefficients, (1) co-integration equation (s) Normalized Co integrating Coefficients: 1 Co integrating Equation(s)

\begin{tabular}{|l|l|l|l|l|l|l|}
\hline RGDP & ASI & MAC & NIC & NIS & INR & INF \\
\hline 1.000000 & 1.3947 & 3.1551 & 1.1810 & -1.5601 & -0.2117 & -0.0561 \\
\hline & $(1.636)$ & $(2.195)$ & $(0.276)$ & $(0.718)$ & $(0.2001)$ & $(0.2791)$ \\
\hline & & & & & & \\
\hline Log likelihood & -992.411 & & & & C & \\
\hline & & & & & 3.8210 & $(1.9720)$ \\
\hline
\end{tabular}

Source: Authors' computation 2021

Johansen procedure is used to identify long-run relationship amongst the co-integrating vectors. Table $3 a$ reports the estimates of Johansen procedure and standard statistics. In determining the number of co- integrating vectors, we used degrees of freedom adjusted version of the maximum eigenvalue and trace statistics, since the existence of small samples with too many variables or lag Johansen procedure tends to overestimate the number of co-integrating vectors. Test indicates 2 co-integrating equation(s) at 5\% significance level. Table 3a presents the result of Johansen co integration test. Accordingly, the Eigen value statistics and likelihood ratio detect each co integrating vectors relationship at $5 \%$ level of significance. This test indicates the presence of a long run equilibrium relationship among variables. As a result, the error correction model is estimated. 
Table 3b

\begin{tabular}{|c|c|c|c|}
\hline Eigenvalue & Likelihood Ratio & 5 Percent Critical Value & Hypothesized No.of CE(s) \\
\hline 0.778006 & 79.17726 & 69.8 & None \\
\hline 0.583731 & 43.05476 & 47.9 & At most 1 \\
\hline 0.543259 & 22.02059 & 29.8 & At most 2 \\
\hline 0.102625 & 3.195716 & 5.15 & At most 3 \\
\hline 0.024567 & 0.596967 & 3.84 & At most 4 \\
\hline 0.022019 & 0.231107 & 2.72 & At most 5 \\
\hline 0.002110 & 0.101281 & 1.58 & At most 6 \\
\hline
\end{tabular}

Note:*(**) denotes rejection of the hypothesis at $5 \%(1 \%)$ significance level. The existence of at least one co-integrating relationship between set variables implies that error-correction models (ECM) exist. The significance of the ECM is an indication of the existence of a long-run equilibrium relationship between that dependent and factors affecting it.

Causality Test

Pairwise Granger Causality Tests

Date: 10/12/21 Time: 20:38

Sample: 20002020

Lags: 2

\begin{tabular}{lccc}
\hline \hline Null Hypothesis: & Obs & F-Statistic & Prob. \\
\hline \hline ASL does not Granger Cause RGDP & 19 & 0.24296 & 0.7875 \\
RGDP does not Granger Cause ASL & & 0.02600 & 0.9744 \\
\hline \hline MAC does not Granger Cause RGDP & 19 & 0.76059 & 0.4858 \\
RGDP does not Granger Cause MAC & & 1.20922 & 0.3278 \\
\hline \hline NIC does not Granger Cause RGDP & 19 & 1.56021 & 0.2445 \\
RGDP does not Granger Cause NIC & & 0.99485 & 0.3945 \\
\hline \hline NIS does not Granger Cause RGDP & 19 & 1.04370 & 0.3780 \\
RGDP does not Granger Cause NIS & & 0.18997 & 0.8291 \\
\hline \hline INR does not Granger Cause RGDP & 19 & 0.38929 & 0.6846 \\
RGDP does not Granger Cause INR & & 0.63778 & 0.5431 \\
\hline \hline INF does not Granger Cause RGDP & 19 & 2.71355 & 0.1009 \\
RGDP does not Granger Cause INF & & 0.17398 & 0.8421 \\
\hline \hline
\end{tabular}

Source: Authors' computation 2021

The results in table above shows the Pairwise Granger causality test among the variables analyzed. The causality result shows that RGDP granger cause ASI, which indicates that as ASI increases, real gross domestic product increases. RGDP Granger cause MAC implies that increase in market capitalization in stock market leads to attraction of more investment in Nigeria economy. 
Most importantly, RGDP also granger cause NIC indicates that there is a positive and direct relationship between RGDP and NIC, the more RGDP we have in Nigeria, the higher the level of economic growth and development. This means that RGDP has contributed significantly to the growth of Nigeria economy during the period under consideration.

The Over-parameterised Error Correction Model.

Dependent Variable: RGDP

Method: Least Squares

Date: 10/12/21 Time: 08:46

Sample: 20002020

Included observations: 21

\begin{tabular}{llccl}
\hline \hline Variable & Coefficient & Std. Error & t-Statistic & Prob. \\
\hline \hline C & $1.62 \mathrm{E}+08$ & $1.38 \mathrm{E}+08$ & 1.172259 & 0.2607 \\
ASL & 1151.635 & 1224.257 & 0.940681 & 0.3628 \\
MAC & 5.869105 & 1804.312 & -1.036132 & 0.3177 \\
NIC & 3.810972 & 207207.5 & -1.839206 & 0.0872 \\
NIS & -1.264350 & 13.48917 & 0.093731 & 0.9267 \\
INR & -3191035. & 5114203. & -0.623956 & 0.5427 \\
INF & -3.599138 & 2572600. & 0.295387 & 0.7720 \\
\hline \hline R-squared & 0.962552 & Mean dependent var & 33328691 \\
Adjusted R-squared & -0.953497 & S.D. dependent var & 35679729 \\
S.E. of regression & 36621667 & Akaike info criterion & 37.93138 \\
Sum squared resid & $1.88 \mathrm{E}+16$ & Schwarz criterion & 38.27955 \\
Log likelihood & -391.2795 & Hannan-Quinn criter. & 38.00694 \\
F-statistic & 11.30733 & Durbin-Watson stat & 1.130182 \\
Prob(F-statistic) & 0.565530 & & & \\
\hline \hline
\end{tabular}

Source: Authors' computation 2021

In table above, the R-squared (R2) of 0.96, which measure goodness of fit, indicates that $96 \%$ of the systematic variations of growth rate in real gross domestic product is explained by the explanatory variables during the period of the study. The overall F-statistics of 11.3 with a low probability of less than $5 \%$, gives clear that the equation is well fitted. The Durbin- Waston statistics of 1.13 indicates the presence of autocorrelation in our specification.

Number of listed securities have a negative relationship with output level ofreal gross domestic product. A one per cent fall in the number of listed securities will decrease the output level of real gross domestic product by 1.26 percent. The F-Statistic shows that we accept the alternative hypothesis and reject the null hypothesis. This means that fall in capital market indicator in the country has had a negative effect on the growth process in Nigeria economy.

All share index, market capitalization and number of listed companies have a positive and significant relationship with output level of real gross domestic product at first difference, hence market capitalization have a strong relationship with sustainable development in Nigeria. The implications of this finding is that the all share index, market capitalization and number of listed companiesup to 2020 has resulted to increases in output level of real gross domestic product in Nigeria with lagged difference. 
The co-efficient of determinant shown that $96 \%$ of the total variations in output level of real gross domestic product is explained by the explanatory variables.

\section{CONCLUSION AND RECOMMENDATIONS}

Given the importance of capital market in economic development, it will be necessary to position the market in other to achieve sustainable development. The results shows that $96 \%$ variations in the RGDP are explained in the model. The overall fitness of the model is explained by the FStatistics value of 11.3 with a low probility of less than 5\%. Findings reveals that the All Share Index (ASI), Market Capitalisation (MAC) and Number of Listed Companies (NIC) have positive but insignificant effect on sustainable development while Number of Listed Securities (NIS), Interest Rate (INR) and Inflation Rate (INF) all have negative and insignificant effect on sustainable development. It is therefore recommended that for capital market can to lead to sustainable development, the more securities should be listed on the floor of the stock exchange, while the rate of interest rate and inflation rate should be reduced. 


\section{REFERENCE}

1. Alam, M.D., \& Hussein, M.A. (2019). The impact of capital market on economic growth in Oman. Financial Studies, 2, 117 - 129.

2. Al-Fakl M 2006. The Nigerian Capital Market and Socioeconomic Development. Paper presented at the $4^{\text {th }}$ Distinguished Faculty of Social Science Public Lecture,University of Benin, 26 July, 9 - 16.

3. Babalola, J. A., \& Adegbite, M. A. (2001). The performance of the Nigerian capital market since deregulation in 1986. CBN Economic and Financial Review, 39(1), 1 - 19.

4. Busch, T., Bauer, R., \& Orlitzky, M. (2015). Sustainable development and financial markets: Old paths and new avenues. Business \& Society, 55(3), 1 - 27

5. CBN (2010). Bullion, 34(4), Accessed December 11, 2021 from https://www.cbn.gov.ng/Out/2016/CCD/BULLION\%20Vol\%2034\%20No4.pdf

6. Dowan, P., \& Odia, J. (2010). An empirical analysis on the impact of the Nigerian capital market on her socio-economic development. Journal of Social Science, 24(2), 135 142.

7. Ehigiamusoe, U. K. (2012). The place of financial market in the development process: Evidence from Nigeria. Journal of Economics and Behavioral Studies, 4(11), 649 - 659.

8. Emeh, Y., \& Chigbu, E. E. (2014). The impact of capital market on economic growth: The Nigerian perspective. International Journal of Development and Sustainability, 3(4), 838 - 864.

9. Inter-American Investment Corporation (2021). Financing sustainability through capital market: A practitioner's guide and toolkit for Thematic Bond. Accessed September 23, 2021 from Thematic_BONDS_MAY26_FINAL.pdf

10. Mishra, P. K., Mishra, U. S., Mishra, B. R., \& Mishra, P. (2010). Capital market efficiency and economic growth: The case of India. European Journal of Economics, Finance and Administrative Sciences, 27, 130 - 138.

11. Nigerian Stock Exchange (2020). 2019 market recap and 2020 outlook. Accessed on December 11, 2021 from https://ngxgroup.com/wp-content/uploads/2020/11/2019Market-Recap-and-2020-Outlook.pdf

12. Oganga, S. (2019). Evolution of capital market. Journal of Research in Humanities and Social Science, 7(7), $55-72$.

13. Ogboi, C \& Oladipo, S. O. (2012). Stock market and economic growth: The Nigerian experience Research Journal of Finance and Accounting, 3(4), 103 - 110.

14. Oluwole, F. O. (2014). Financial development and economic growth nexus in Nigeria. Global Journal of Commerce and Management Perspective, 3(5), 231 - 241.

15. Osho, A. E. (2014). The role of stock market on Nigeria's economic development. International Journal of Scientific and Research Publication, 4(4),1 - 7.

16. Oteh, A. (2018). Leveraging capital market for sustainable development. World Bank $50^{\text {th }}$ ICMA General Meeting and Conference in Madrid, Spain. Accessed September 23, 2021 from https://www.worldbank.org/en/news/speech/2018/06/01/leveragingcapital-markets-for-sustainable-development.

17. Riman, H. B., Esso, I. E., \& Eyo, E. (2008). Stock market performance and economic growth in Nigeria: A causality investigation. Global Journal of Social Science, 7(2), 85 91.

18. Shi, L., Ham, L., Yang, F., \& Gao, L. (2019). The evolution of sustainable development theory: Types, goals and research prospects. Accessed December 12, 2021 from doi:10.3390/su11247158 
19. Udo, G. C., Nwezeaku, N. C., \& Kanu, S. I. (2021). Effect of capital market development on the economic growth of Nigeria. International Journal of Innovation and Economic Development, 7(2), 30 - 46.

20. UNCTAD (2014). World Investment Report 2014. Accessed December 12, 2021 from https://unctad.org/system/files/official-document/wir2014_en.pdf

21. UNDP (2015). The Sustainable Development Goal in action. Accessed on December 10, 2021 from https://www.undp.org/sustainable-development-goals

22. Waygood, S. (2016). Capital market at the nexus of sustainable development. In F. Dodds \& J.

23. Bertram (Eds.). The water, food, energy and climate nexus: Challenges and on agenda for action (229 - 245). New York, NY: Routledge.

24. World Economic Forum (2021). The global risk report 2021. Accessed September 23, 2021 from http://www3.weforum.org/docs/WEF_The_Global_Risks_Report_2021.pdf 